\title{
Changing Dynamics Of Gendered Livelihoods Practices In Post Crises Of Swat Northwest Pakistan
}

\author{
Noor Elahi \\ Department of Development Studies \\ COMSATS University Islamabad, Abbottabad Campus
}

\begin{abstract}
This research attempts to focus on the changing dynamics of livelihoods practices among gender, and how conflict and flood crises (2005-2010) effected the various needs of livelihoods of the social classes in Swat valley of northwest Pakistan. Qualitative methods; formal/informal interviews, focus groups discussion, key informant interviews and participant observation, were used to explore the dynamics of changes in occupations, household dependency and those factors which influenced the changes accessing livelihood resources. The paper revealed that those households depending agriculture, small business and labour in market have been highly affected during conflict and flood crises in comparison to those households who were depending on remittances, public and private jobs and skilled works. The study found that the livelihood dependency of the households in all villages was based on agricultural and natural resources, which has changed to market and jobs based oriented resources. The factors like economic development, migration, conflict and displacement, and post conflict development have created diverse opportunities of livelihood resources for men and women, which brought social and cultural changes in the livelihood practices between genders at household level. The research emphasizes on the long-term livelihoods strategies and gendered equal opportunity policies by government and NGOs after the crises, which may improve the social statuses of the men and women.
\end{abstract}

Keywords: Gender, Livelihoods, Changing Perspectives, Post Crises Development.

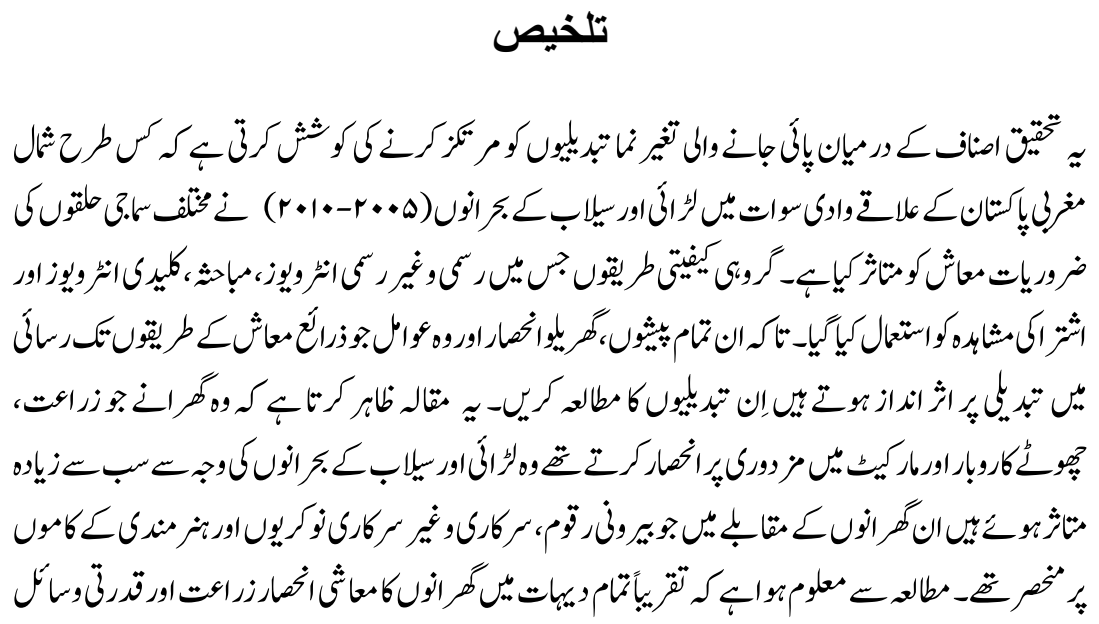




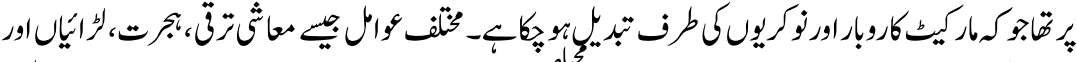

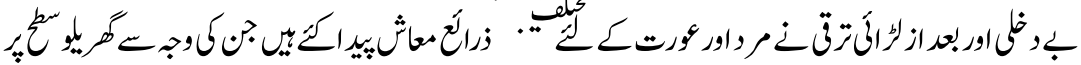

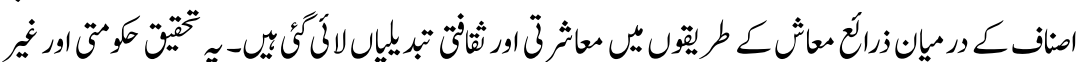

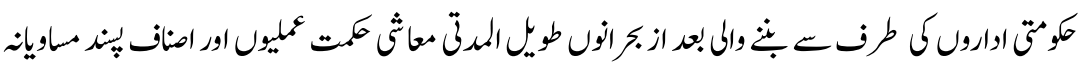

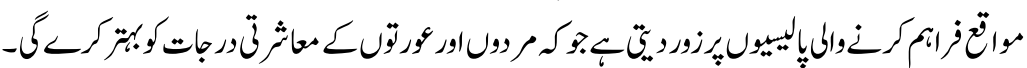

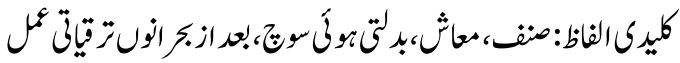

During recent decades, Swat has suffered various intense crises in the form of militant conflict, followed by Pakistan military operations against the militants, and floods disaster. In the Swat district, militant conflict got momentum after 9/11 incidents and during 2005-08, the militant occupied the major areas of the Swat including urban area of Mingora City. After a number of peace deals with militants, the Government of Pakistan (GoP) carried out a military operation RahiRast (strait path) in 2009, however, at the same time more than 1.2 million of population were displaced only from the Swat valley (WB and ABD, 2010). The operation was successful in term of ousting the militant from the Swat. The government along with support of NGOs were in process of the resettlement and rehabilitation of the internally displaced people that historical flood disaster occurred in 2010. Both these crises (militant conflict 2005-09 and flood 2010) have had devastating effects on socio-economic aspects of the Swat valley (Salman, 2012). The livelihood needs of the people increased and priorities changed due to the internal displacement of more than 141,582 families from the Swat and physical losses to agricultural land and crops in 2009-10 (CPPR, 2010). The closure of the tourism sector further reduced the extent of private jobs and related business. A survey conducted during the conflict period in Swat showed that most of households before the conflict were able to cover the cost of food, utilities, education, health and transportation by themselves (Khan, 2009; SDPI, 2012). However, "the conflict and flood have changed this for many people by severely constraining households' ability to secure a stable and decent income" (SDPI, 2012: 11). The people of Swat have had to carry a huge burden in terms of losses to the local economy and their livelihoods (Salman, 2012). To recover the losses, a rehabilitation and reconstruction ( $\mathrm{R} \& \mathrm{R}$ ) process was initiated jointly by the Government of Pakistan including the Pak Army, international/foreign donors and NGOs. The crises themselves besides the humanitarian aid during and after the crises, have to some extent changed the dynamics of gendered livelihood practices and accesses to resources for all groups of people in the region.

Gender roles and relations in accessing livelihood assets (physical, financial, social, natural, and human) are not always the same, mostly in under develop countries, because of different cultural perspectives, resources and living patterns (Sen, 2001). The argument is that gender roles and responsibilities are socially and culturally constructed in livelihood practices, following the patriarchal 
structure of the society to legitimize the unequal gendered division of labor and access to assets. In the Swat Valley, people have multiple livelihood sources; the livelihood assets in the area are closely linked with each other and gender roles are more prominent in respect of some assets for example social, human and natural, while they appear to be of little significance in physical and financial (Khalid, Nyborg \& Khattak, 2015). The Swati people are involved in a variety of occupations to fulfill the livelihood needs of their households (Shah, 2010). All the ethnic groups depend on multiple sources of income. In the rural areas of Swat, over half of the working populace is associated with agribusiness, forestry resources and fishing, while $27 \%$ work as representatives in government and private sectors, trailed by $12 \%$ deals small scale businesses, lodgings while the rest of households are engaged with development, transport, and skilled work (CPPR, 2010). Women work in both government and private sectors and constituted almost $30 \%$ of the total employed population in 1998 (District Census Report, 1998).Majority of the population in Swat valley belong to patriarchal Pukhtoon ethnic group and accept Pukhtoonwali (a code of ethic or way of life). Overall, social framework in Khyber Pakhtunkhwa including Swat district, where this study has been conducted expect that male should be the fundamental provider for food subsistence in a family, while females are mostly confined to a reproductive works and household activities (Ahmad, 2006; Lindholum, 1982; Qayyum, 2010).In Pukhtoon society, women have a very limited role and level of power in relation to decision making and access to resources, because of male dominance and a patriarchal structure (Naz \& Rehman, 2011). According to Seigmam \& Sadaf (2006), women confinement inside the spatial limit to the household as because of their sexual behavior connected to male honor; and similarly women's motilities are controlled to ensure the family respect. In Swat females are for the most of time engaged with family inside the household while males are made responsible for external works following the cultural norms (Rahim \& Viaro, 2002). However, a number of socio-economic, media, education, migration and lastly the conflict and flood crises factors have highly effected the gender roles and relations during the last couple of decades.

This paper focus on how are decisions made at household level in Swat society about division of labor in earning livelihoods, child care, income distribution, and access to resources? Who is responsible for what activities, and who carries out such activities? How the conflict and flood crises have changed these assigned roles to men and women, boys and girls particularly in relation to livelihoods accesses in post conflict development?

\section{Literature Review}

Gender has been defined as the cultural and sexual division of works between male and female (Smyth, 2007). In the developing countries the word gender has been confused and often used for women. Gender relations explained as the type of social and cultural diversity among people relating to stake in assets, livelihood 
decision making, communal aspects as well as future plans for families and overall society (Momsen, 2010; Jane, 2002). Such kinds of gender differences are developed based on ethical, religious, traditional, financial and cultural elements (Moser, 1989).

Chambers and Conway (1992) defined livelihood as the relations of people with assets and choices they possess to practice the alternatives options so as to fulfil the subsistence needs required for survival. The researchers and development professionals applied various livelihood and gender analysis frameworks in relation to poverty reduction, vulnerability strategies and the sustainability of interventions. Schafer $(2002,16)$, defined livelihood analysis framework (LAF) 'an instrument for analysis intended for providing foundations, which consists of the multifaceted sources of income of the society in a particular time, and most importantly include the trajectories and changing aspects'. There are several wellknown LAFs, such as the framework for Policy Analysis of Rural Livelihoods e.g. Scoones and Carney, 1998; and Ellis, 2000; and the Sustainable Livelihood Framework (SLF) e.g. DFID, UNDP and Care International. These frameworks contain more or less the same basic elements, namely livelihood resources, strategies, and outcomes. The guiding principles are common to the different organizations that work with sustainable livelihood approaches, although the details of the frameworks and methods may differ (Carney, 1999). A livelihood analysis framework emphasis on how households access their livelihoods and classifies the various sorts of resources and activities which families embrace to access and meet their basic needs (De Satge, 2002). Although, the above mentioned LAFs do not focus accessibility problems of different ethnic groups to assets, or gender relations in the community.

The DFID (1999), LAF focuses on livelihood strategies of households, the dynamics of changes in livelihood resources and the way in which people can influence the institutions and process that impact on their lives. On the other hand, a gender analysis framework (GAF) is a method for better understanding of culture, expressed in the construction of gender identities and inequalities (Pasteur, 2002). GAF uncovers the aspects of different men and women problems for example livelihood activities, relationships, accesses to and control over and other requirement because it has been designed at grass root level (DFID, 2002). Therefore, to focus on the issues of accessibility to various livelihood assets and dynamics of changes among both men and women to livelihoods assets, LAF and GAF of the DFID (2002) are used in this study. Further, a GAF also helps to understand the way in which gendered livelihood practices are constructed and how they change. Since Swat is the Pukhtoon ethnic dominant society, therefore, it might be necessary to understand the values articulated to construct the gender characteristics as well as accesses linked with HHs economies. 


\section{Methodology}

The area selected for the research was Swat district lies in the North of Khyber Pakhtunkhwa (KP). The data was collected for my $\mathrm{PhD}$ study during 2013-14 while the area was revisited in the 2016 for more indept information. The Swat district borders Buner and Malakand to the south, Lower and upper Dir districts on the west, Shangla and Kohistan to the east and Chitral and Gilgit to the north. The total area of the district is $5065 \mathrm{~km} 2$ with a population of about 1.80 million (Salman, 2012). Historically Swat remained very famous for rich natural resources and scenic beauty. The people use multiple sources for their livelihood to fulfill the survival needs of the families. Most of the people still depends on agri related resources along with government and private jobs, foreign and domestic remittances (Shah, 2010).

The study employed qualitative approach, keeping in view the interpretive nature of the research. The methods used for primary data collection are formal/informal interviews, focus groups discussion, key informant interviews and participant observation. For selection of villages, households and respondents, purposive sampling method applied. Purposive sampling is a strategy in which decision concerning the individual or households to be included in the sample are taken by the researcher on the basis of some criteria in order to get relevant information and specific information (Palys, 2008). In total five villages, two each from upper and lower swat and one from central area were selected to have in-depth information of the diverse effects of crises and the changes occurred in the livelihood patterns. 50 households were selected 10 each from the villages and at average 2-4 households were selected on the basis of ethnic and social status differentiation including Puhktoon, Syed/Mian, Gujjar, Kohistnai, tenants, shopkeepers, govt. and private employees and general labour class. Formal interviews were conducted with 28 heads of the households including six women headed households and 22 male non-headsof households (other member than head of the household). Key informant interviews were conducted with (six men and two women) including academic researchers, local political and religious leaders, and government and NGOs officials working in the study area to make the data reliable and informative.

For more in-depth and relevant information five focus group discussions one each in village with men group of 6-8 persons were held, however, focus group discussion with women was not possible due to cultural and social constraints. Besides these, applying participant observation methods, informal interviews were held with different categories of the populations while visiting and staying in different part of the Swat. The researcher used to participate in agricultural activities, marriage and death ceremonies, and attended the community livelihood and skills development trainings imparted by government of Pakistan and NGOs. 
To support the primary data, secondary data was collected from government and NGOs offices in Swat, Peshawar and Islamabad. Furthermore, Online sources (websites, published journals, books), development project reports and case studies were made part of the search. Households survey was analyzed through MS Excel while interviews were analyzed through N-Vivo 10 software, and interpretive method was used for analysis of qualitative data. Some of the information presented in discussion are based on personal observations documented during field work in 2013-14.

\section{Results and Discussion}

People of Swat are involved in a variety of occupations to fulfill the livelihood needs of their households. All the ethnic groups depend on multiple sources of income. In all the selected villages the people have various occupations. Traditionally the hierarchy of occupations is Khans (landlord), Mian/Syed (Holy descent group), Paracha (trader), Sunar (goldsmith), Karigar (blacksmith), Muzdoor (daily wage worker), Mazari (tenant) and Naiye (barber). (See also Ahmad, 1980: Barth, 1965, 1981). Although the same occupations are currently found in the villages, but the roles in relation to different livelihood sources have changed over the last two decades. Several respondents in the villages stated that because of opportunities of education and foreign countries migration, several households occupations have changed to labor and from tenants to businessmen, skilled workers and government designators. For example, among paracha, Sunar, karigar, and tenant groups, there were teachers, lady health workers (LHWs), clerks, and persons working in other government administrative positions. Over $80 \%$ of respondents agreed that Pakhtoonwali is the accepted way of life for all these groups. However, some non Pukhtoon group such as Nayee, Kaarigar and Gujjars are not bound to follow the Pakhtoonwali. Although majority of these groups have changed their status because of migration in and outside the country and earned handsome money and purchased properties in the Swat. Nevertheless, differentiation remains in social relations and class hierarchy between Khans/Syed groups and other professional groups.

\section{Livelihood Dependencies of Households}

The Government of KP and UNDP Report (2011) shows that at average livelihood dependency of HHs monthly income in KP is that crops and livestock which make up $15 \%$ of total income, while international and national remittances make up $18 \%$, and the rest are based on multiple livelihood resources and there is diversification in the different regions. A rapid assessment report conducted by Save the Children (Khan, 2009) in Swat reported that before the crises, agriculture was the main source of livelihood of $44 \%$ of surveyed communities, followed by skilled jobs in government and private industries $(29 \%)$, remittances $(8 \%)$, with 
the remaining proportion in semi-skilled or unskilled, retail and labor. This study found through the household socio-economic survey that livelihoods in the selected villages depend mainly on agriculture, including forestry, livestock and fisheries, followed by government and private services, national and foreign remittances, and daily wage labor. Details of household dependency on various livelihood sources in both the selected villages are given in Figure 1.

Figure 1: Dependency of the people on various sources of livelihoods in percentages

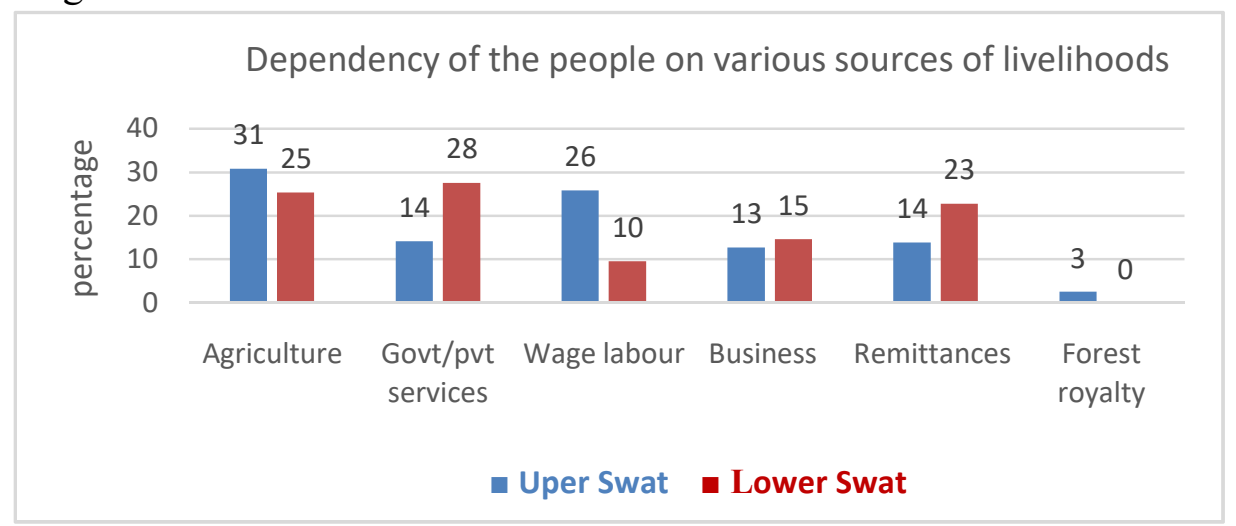

Source: Field survey 2013-14

The figure shows that the important source of income of the 31 percent households in upper Swat is agricultures while 25percent in lower swat. The trends towards the government and private services are high in lower areas because of access to urban areas and opportunities of small scale industries. In upper Swat dependency on labour of daily wages in hotel, restaurants, transports etc. was greater. The reason for this is that during the summer season when tourism is on peak, the working groups in upper areas are therefore, engaged in the hotel and restaurants businesses, transport and labor in agricultural sectors. The dependency on remittances (national or international) is 14\% in upper swat while $23 \%$ in lower areas households depending on family type and size(the average household size in Swat was nine persons per HH as per CPPR report 2010), the percentage may increase. For example, extended family income depends on multiple sources, while nuclear family income may depend on only one or two sources such as government service, agriculture or labor or remittance. According to the HH survey in the selected villages, almost $70 \%$ of the population lives within an extended family system, and the rest are in a nuclear family system. The following section discusses how men and women within the HHs perform different types of activities. 


\section{Gender Based Daily Activities at the HH Level}

Daily activities within households based on gender involvement vary among different ethnic groups in all the selected villages. Details of the major activities carried out by men and women are given in Table 1. The table does not include salaried jobs, the labor market, business, or any other livelihood activities, because in the majority of cases only men are involved in these activities.

Table: 1

Daily activities of men and women in selected villages

\begin{tabular}{|l|c|c|c|c|l|}
\hline \multirow{2}{*}{ Activity } & \multicolumn{2}{|c|}{$\begin{array}{c}\text { Upper Swat } \\
\text { Villages }\end{array}$} & $\begin{array}{c}\text { Lower Swat } \\
\text { Villages }\end{array}$ & \multicolumn{2}{|c|}{ Remarks } \\
\cline { 2 - 6 } & Male & Female & Male & Female & \\
\hline $\begin{array}{l}\text { Agricultural } \\
\text { activities }\end{array}$ & 3 & 1 & 3 & 1 & $\begin{array}{l}\text { Women from four tenant } \\
\text { families are highly involved }\end{array}$ \\
\hline Grazing livestock & 3 & 0 & 3 & 0 & $\begin{array}{l}\text { In upper Swat women also } \\
\text { involved }\end{array}$ \\
\hline Fuel wood collection & 2 & 1 & 2 & 1 & $\begin{array}{l}\text { Only women in poor HHs } \\
\text { collect fuel wood from the } \\
\text { mountains }\end{array}$ \\
\hline Fodder collection & 3 & 2 & 3 & 1 & $\begin{array}{l}\text { Women in tenant HHs collect } \\
\text { fodder from agricultural fields }\end{array}$ \\
\hline Water collection & 1 & 3 & 0 & 3 & $\begin{array}{l}\text { Some HH in upper swat } \\
\text { collect water from spring, and } \\
\text { male also involved }\end{array}$ \\
\hline Livestock care & 0 & 3 & 1 & 3 & $\begin{array}{l}\text { Males in tenant HHs in lower } \\
\text { areas also take care of } \\
\text { livestock at the HH level }\end{array}$ \\
\hline $\begin{array}{l}\text { Local poultry } \\
\text { farming }\end{array}$ & 0 & 3 & 0 & 3 & $\begin{array}{l}\text { In poultry farms as a business } \\
\text { outside HHs, males have the } \\
\text { main task }\end{array}$ \\
\hline $\begin{array}{l}\text { Cooking/cleaning/ } \\
\text { washing }\end{array}$ & 0 & 3 & 0 & 3 & $\begin{array}{l}\text { Male living in hostel or } \\
\text { foreign countries for jobs } \\
\text { involved }\end{array}$ \\
\hline Child care & 1 & 3 & 1 & 3 & $\begin{array}{l}\text { Elderly men are involved in } \\
\text { child care }\end{array}$ \\
\hline $\begin{array}{l}\text { Shopping at the } \\
\text { market }\end{array}$ & 3 & 0 & 3 & 1 & $\begin{array}{l}\text { Little involvement of women } \\
\text { in purchasing HH items at } \\
\text { lower swat }\end{array}$ \\
\hline
\end{tabular}

$0=$ No involvement $1=$ little involvement $2=$ Much involvement $3=$ Main task Source: Field survey 2013-14

Women perform the bulk of work within households, including cooking, cleaning, washing clothes, dishes, child care, livestock care, storage of crops, and collection of water. All these are unpaid jobs with little recognition in society. Among males 
these are culturally assigned tasks to women and women do it without any hesitation. An employed woman of NGO at Madyen said 'the patriarchal system demand women like us to perform all the households works as other (nonemployed women)do. Such kinds of social obligations increase the working load on women, and they have to perform at one time the triple roles'.

Razavi and Miller (1995: 27) claim that 'it is through gender relations that men are given a greater capacity than women to mobilize a variety of cultural roles and material resources in pursuit of their own interest'. Women respondents were of the view that there is no such compulsion on men and women to perform domestic activities in the Islamic religion. However, due to cultural orientation male avoid participating in domestic activities. However, men were of the view that doing household domestic works such as cleaning, washing and cooking are considered as despicable demonstration and in defiance with the values of Pakhtoonwali. Moreover, women mobility outside the home for buying food item or shopping is considered violations and condemned in the society.

Based on observations and discussions with various people in the selected villages, the analysis shows that the functioning of households and fulfilling livelihood needs of families are both important responsibilities, for each gender respectively. Men perform outside work and earn a livelihood for their $\mathrm{HH}$ members, while women support them by performing equally important domestic activities within the household. According to Collier(1994, 140), 'one is a worker only because of one's relation to the employer, a husband only because of one's relation to the wife, a buyer only because of one's relation to the seller....... In this society domestic activities at household level are related to women identity because external work related to men personality.

\section{The Changing Trend in Practical and Strategic Gender Needs in Terms of Livelihoods}

Pakistan's development indicators under the Millennium Development Goals are not encouraging. According to the Human Development Report (2013), Pakistan is ranked at 146 in terms of the gender gap and the Human Development Index. Nevertheless, with international organizations support such as the UNDP, CEDAW, and international donors, the struggle for promotion of gender inequalities brought about change to a certain extent while working towards the achievement of Millennium Development Goals. The 'glass ceiling' that separates women from their male colleagues by restricting them to within the boundary of the household is now less rigidly enforced. Furthermore, factors such as education, the media and economic development have strengthened the concept of gender equality and raised awareness about women's rights.

Despite of moderate development in Swat, the consecutive crises of the militancy conflict during 2005-09, followed by the flood disaster in 2010, have reduced the 
extent of progress towards gender equality. These crises caused huge internal displacement and losses to livelihood assets and infrastructure, which significantly affected the practical and strategic gender needs of the entire population of Swat (Shah, 2010). Fortunately, after the crises, gender equality has remained one of the core areas in government and NGOstrategic and development plans. Similarly, rehabilitation and reconstruction activities are on full swing but until 2013, no specific gender policy has been developed.

Practical gender needs refer to food, water, shelter, health and security issues, where roles assigned to men and woman have been affected in several ways. The social structure in Swat expects men to fulfill the practical gender needs of their $\mathrm{HH}$ members. However, a key informant in Swat said that during the displacements, and even in the flood disaster, women participated equally in mitigating the needs of families. For example, while living in camps during displacement the male had no source of income, families were totally dependent on aid provided by the government and humanitarian agencies basic needs. Foods and other necessary items distributed by government and NGOs were collected by women and children. Female headed HHs were more prone and faced difficulties in for attaining livelihoods as the cultural system does not allow women to work outside the home. Due to the loss of family income, the burden on poor people with little or no cash income increased, particularly for mothers who were restricted to their traditional roles (Bari, 2010). The majority of respondents revealed that women and children were badly affected by the crises in terms of health, nutrition, shelter, privacy and food accessibility. Before the Army operation, women were restricted to their houses by the Taliban and were prohibited from continuing with their jobs. During an interview, one of the LHW/Visitor told that in 2008-09, the majority of LHW (V) stopped the provision of services to mother and children in different assigned areas, this not only reduced the regular income of the LHW but increased the suffering of the lactating mothers and new born children. Although some the LHWs have left their jobs because of murder and kidnapping threats, currently there are no such restrictions and the trends are changing; and in the study areas all the LHWs found able to take up their duties again and at the same time many other women have been hired by government and NGOs.

Strategic gender needs refer to equality and the right to access education, health services, wages and resources. The crises destroyed the local infrastructure of roads, schools, health facilities, hotels and other small industries, and in turn reduced rural and urban livelihood resources (WB and ADB, 2009). The gendered differences in accessing strategic opportunities increased during the conflict. Women were restricted from education, jobs and gaining skills. A Social Welfare Department officer at Mingora said "by destroying 60 percent and above women's vocational training centres and steeling of equipment by militants, women 
participation in community organizations and vocational trainings, has been adversely affected". However, in this study, we observed that post-conflict development has, to some extent, changed the trend among men and women from labor to self-employment in all the selected villages.

According to the household survey and interviews, the changing livelihood trends among males are towards international migration for labor and business, followed by government and private sector services, local level small-scale businesses like property, transport, shops, electrical and mechanical works, with agriculture being the lowest priority. The majority of poor households surveyed in the villages responded that before the crises they were totally dependent on labor in agriculture, but this sector was highly affected by the crises, and in response a number of poor households were financially supported by humanitarian aid.

Such factors influenced movement to private sector jobs and self-employment, and a trend away from agri-based work to the services sectors. A woman NGO official in Upper Swat said that 'the trend among women towards skills development has increased, but the issue of women's mobility is hindering the interest and progress'. Nevertheless, the policies and strategies adopted by the government and NGOs to address strategic gender needs are pleasing. According to government and NGO official's, the livelihood policies cover gender needs equally, through various income generating interventions. The rehabilitation and construction of over $75 \%$ schools, improvement in existing health facilities, restoration of vocational centres, and infrastructure development of official buildings, roads, hotels, and agricultural development as well as tourism development has brought changes in livelihoods opportunities for both males and females. According to an impact assessment report (Surani, 2011), the USAID job project imparted skills training to 1375 workers including $30 \%$ women in various sectors in Swat. The report reveals that $30 \%$ of the beneficiaries changed their occupation from agricultural wage labor to skilled work. As a result, the overall economic condition of $56 \%$ of households has improved. Such kinds of opportunities have changed the decision-making processes about the use and accesses of livelihood resources.

\section{Decision Making at the HH Level and Division of Labor in Livelihood Activities}

It is always difficult to gain an accurate picture of decision making at the household level and the division of labor in livelihood activities. This section discusses how decisions are made at the HH level, and who makes the decisions, particularly in terms of access to livelihoods assets. 
The anthropological and sociological researches conducted by Barth, Ahmad, Lindholm, Benedicta, Amine Ahmed and many local historians on Swat and other parts of northern Pakistan found that men are the main breadwinners and decision makers within and outside the home. Confinement of women in the household boundary-walls of the home, and to reproductive and community roles, and their sexual behaviour is linked to upholding the households' honor. During field work, questions were asked from both men and women: Do men and women have equal access to the distribution and use of income sources like land, property, cash income and skills at the HHs? The reply was always "No", accompanied by the explanation that men have the authority and access to all resources and decision making. Only two female respondents - one teacher and one NGO worker replied "Yes" but qualified this by saying that only a few households give equal access to such resources. Other reasons given for their agreements that earning women have major roles in decisions about livelihoods as well as access to resources within the household.

Using the ethnographic tool of probing by asking sub-questions, the majority of respondents of either gender revealed that sometimes women within the household are very strong, particularly among the wealthy class referred (Khan families). In such households, men are expected to seek advices from woman (their mother, wife) concerning the sale or purchase of land, property, or a business; house construction; education of children; and particularly marriages of either sons or daughters. This trend particularly got momentum in the post crises development of NGOs and government organizations where women participation in livelihood earning have been prioritized in reconstruction interventions.

Pukhtoon culture is centuries old where males are not bound to give equal share to female in land and other properties. Male respondents emphasized that there is no harm to pay shares to sister, daughter or wife, however, to avoid any kind of mishap in the family and to defend families from paighoor (ostracism) by outsiders and to keep Namous (women honour), the Pukhtoonwali code of ethics must be adhered to. Similarly, women believe in the same values, namely that if they ask for land rights from their father or brother, this would bring paighoor and shame to women and would be detrimental to the family honor. 'In Pukhtoon culture, the importance of Zar (gold), Zan (women) and Zamin (land) are the core values of Pukhtoonwali, which further shape the local ideology where the inheritance and property rights go in favor of males' (Naz and Rehman, 2011: 27). However, due to recent increases in literacy, awareness through media and communication and access to judicial courts supported under post crises development initiatives, women have started to claims their share in land and properties and this has changed the tendencies toward equal rights to women. There are several cases found in which women have been granted their rights. In view of above discussion, the research can argue that by creating more 
opportunities for women in various fields may bring changes in social and culture perspectives, and women can get more access to livelihood resources and this will gradually improve gender equality.

\section{Conclusions}

The gender perspective is often applied to a variety of social phenomena, and is critically explored on the basis of women's interests regarding sex discrimination, inequality, rights, male dominance, gender bias etc. The theoretical approach of social constructionism and theories developed on feminism and gender, provide basic knowledge and ideas based on historical facts, but in reality, these theories may not necessarily be applicable in the same way in which they were developed. Based on observations and discussions with various people in the study area, the analysis shows that the functioning of households and fulfilling livelihood needs of families are both important responsibilities, for each gender respectively. Men perform outside work and earn a livelihood for their household members, while women support them by performing equally important domestic activities within the household. The ontological and epistemological aspects of gender relations explore to uncover what types of roles, relations and reality exist in various historical and cultural backgrounds. The research investigated various aspects of gender functions, not only for biological needs but also in terms of practical and strategic gendered livelihood needs. In Swat District of Pakistan, gender roles in daily household activities are socially and culturally constructed in the context of the Pukhtoonwali as a code of conduct. Gender roles in the rural study area remain very conservative and different from the practices accepted in more developed societies. Accessibility to livelihood resources including education, health, jobs and socio-political aspects among gender of various ethnic groups is not equal. The Khan families have still dominated political and economic roles and controlled the overall structure of the Swat valley.

This study found that there is diversity in livelihood dependency and occupations of different social and ethnic groups in the selected villages. However, there is evidence of an increasing trend in changing occupations, particularly after the crises of 2009 (conflict and displacement) and 2010 (flood). Although, the analysis shows that households depending on agriculture, labor, and local business were more affected in terms of livelihoods during and after the crises, while people in government services or professional occupations like education, skills and remittances were less affected in terms of economic losses. Recent changes in policies and strategies of the government and NGOs after the crises have created opportunities for both men and women to participate in several livelihood interventions in both the agricultural and non-agricultural sectors. The majority of male household members now seek migratory labor, jobs and business, followed by services in the government and private sectors. Although, women still have limited productive livelihood opportunities in Swat. 
Women's mobility to the market for shopping and for leisure time is still restricted in rural villages, due to cultural values of honor and avoiding shame; however, trends towards education opportunities have increased. However, mobility and accesses to social and economic resources has been provoked by conflict, post conflict development, displacement and current economic development, and media attention. On the other hand, the crises adversely affected social relationships and cooperation between various ethnic and social groups. The key informants stated that the crises had improved the livelihood conditions of the majority of poor households through the provision of diverse livelihood opportunities to men and women; while income of the majority of wealthy and middle-class households has been significantly reduced. Government and NGOs should prioritize the strategic gender needs in their development policies and strategies so as to provide equal opportunities to men and women for secure as well as sustainable livelihoods resources.

\section{Recommendations}

This research based on responses from the community as well government and NGOs officials suggest the following recommendations for future planning and research.

- In-depth researches on the post crises development policies of government and NGOs are needed to fulfill the gap of gender marginalization in term of provision of equal opportunities in the development interventions.

- Long-term development strategies should be adopted particularly in the post crises situation in comparison to focusing on short term policies, this will not only help the affected communities in compensation of the initial damages but will provide multiple livelihoods opportunities to both genders.

- Strategic gender needs should be prioritized in the development strategies of government and NGOs to provide equal opportunities to men and women for secure as well as sustainable livelihoods resources.

\section{References}

Ahmad, S.A. (1980).Pukhtoon Economy and Society - Traditional Structure and Economic Development in a Tribal Society, London: Routledge and Kegan Paul.

Ahmed, A. (2006).Sorrow and Joy among Muslim Women: the Pukhtoon of Northern Pakistan, London: Cambridge University Press. 
Ali, F. (2012). The Genesis of Militancy in Swat: Social and Political Implications. Unpublished M. Phil thesis, Department of Peace and Conflict Studies, National Defense University Islamabad.

Bari, F. (2010). Gendered Perceptions and Impact of Terrorism/ Talibanization in Pakistan, Heinrich Boll Stiftung, Pakistan.

Barth F. (1965). Political Leadership among Swat Pathans. London, New Jersey: The Athlone Press.

Barth, F. (1981).Features of Person and Society in Swat. Collected Essay on Pathans, London: Routledge and Kegan Paul.

Carney, D. (1999).Approaches to Sustainable Livelihoods for the Rural Poor, London: ODI Publications.

Chambers, R. \& G., Conway (1992).Sustainable Rural Livelihoods: Practical Concepts for the $21^{\text {st }}$ Century. IDS Discussion paper no. 296.

Collier, A. (1994).Critical Realism: An Introduction to Roy Bhasker's Philosophy. London: Verso, chapter 5, p. 140.

CPPR (2010). District Swat: Socio-economic Baseline and Displacement Impacts, Islamabad: Center for Public Policy Research (CPPR), available at http://cppr.edu.pk/files/Swat_Report.pdf

De Satge, R. (2002) Learning about Livelihoods, 'Insight from Africa', South Africa and Oxfam GB London: PERI Publications.

DFID (2002). Sustainable Livelihoods Guidance sheet (4.3), London: Department for International Development (DFID), available atwww.livelihoods.org and http://www.eldis.org/go/topics/resource-guides/livelihoods

District Census Report, Swat. (1998). Islamabad: Government of Pakistan, Bureau of Statistics.

EDSR, (2012). Annual Statistical Report of Government Schools, Peshawar, Elementary and Secondary Education Department, Education Department Statistical Report, Government of KP.

Ellis, F. (2000).Rural Livelihoods and Diversity in Developing Countries, New York: Oxford University Press. 
Government of Khyber Pakhtunkhwa and UNDP Report. (2011). Khyber Pakhtunkhwa Millennium Development Goals, Peshawar, Pakistan.

Human Development Report (2013). The Rise of the South. Human Progress in the Diverse World. New York: United Nations Development Program (UNDP). Available on http://www.gm.undp.org/content/dam/pakistan/ docs/MDGs/MDG2013Report/UNDP_Summary.pdf, Chapter 15, Gender Inequality.

Jane, L. P. (2002). Gender and Empowerment: New Thought, New Approaches, London, Arnold.

Khalid, A., Nyborg I. \& Khattak, B. N. (2105). Whose Property and Whose Authority? Gendering the Legal and Customary Practices in Ownership and Accesses to Land. A Case of Swat Pakistan, Journal of Rural Studies. DOI: http://dx.doi.org/10.1016/j.jrurstud.2015.07.004

Khan, S.F. (2009).Rapid Assessment Report of Swat District, NWFP Pakistan, Islamabad: Save the Children.

Lindholm, C. (1982).Generosity and Jealousy: The Swat Pukhtoon of Northern Pakistan, New York: Columbia University Press.

Momsen, J. (2010).Gender and Development, $2^{\text {nd }}$ ed., London, New York: Routledge.

Moser, N. C. (1989). Gender Planning in Third World: Meeting Practical and Strategic Gender Needs, World Development, vol.17:11, pp.1799-1825.

Naz, A. \& H., Rehman (2011). Pukhtoonwali Versus Islam: A Comparative Analysis of Women Rights in Islam and their Violation Under Pukhtoonwali in Khyber Pakhtunkhwa, Pakistan', International Journal of Humanity and Social Sciences, vol.1:II,pp.22-32.

Palys, T. (2008). Purposive Sampling. In L. M. Given (Ed.). The Sage Encyclopedia of Qualitative Research Methods (Vol. 2). Sage: Las Angeles, pp.697-8.

Pasteur, K. (2002) 'Gender Analysis for Sustainable Livelihoods Frameworks, Tools and Links to other Sources', available at http://www.eldis.org/go/ home\&id=41450\&type=Document\#.UwIZa_ldXwk_date:10-2-2014 
Qayyum, B. (2010). Dastane Swat: The Historical, Social and Cultural Perspectives of Swat, Kabal Swat: Jan Kitab Cover and Media Service Publishers.

Rahim, I. \& Viaro, A. (2002).Swat: An Afghan society in Pakistan Urbanization and Change in a Tribal Environment, Karachi: City Press.

Razavi, S. \& C., Miller (1995). From WID to GAD: Conceptual Shifts in the Women and Development Discourse, Occasional paper 1, Geneva: United Nations Research Institute for Social Development, UNDP.

Salman, B. (2012). Socio-economic conditions of post conflict Swat: A critical appraisal', Tigah, a Journal of Peace and Development(2), Islamabad: FATA Research Center.

Schafer, J. (2002).Supporting Livelihoods in Situations of Chronic Conflict and Political Instability: Overview of Conceptual Issues, London: Overseas Development Institute, working paper no. 183.

Scoons, I. (1998).Sustainable Rural Livelihoods: A Framework for Analysis, London: IDS, working paper no. 72.

SDPI. (2012).Livelihoods, Basic Services and Social Protection in northwest Pakistan, Working paper no. 5, Sustainable Development Policy Institute Islamabad, Secure Livelihood Research Consortium, ODI, UK.

Seigmann, K.A. \& T., Sadaf (2006). Gendered Livelihoods Assets and Workloads in Pakistan North-West Frontier Province, in SDPI (ed.) Troubled Times: Sustainable Development and Governance in the Age of Extreme, Islamabad, SDPI and City Press.

Sen, A. (2001).The Many Faces of Gender Inequality. The New Republic, vol.225:2, pp.35-40.

Shah, A. (2010). Households' Livelihood Trajectories in the Context of Man-Made and Natural Disasters: A Case Study from Swat, Pakistan. Masters Thesis; Department of Urban and Rural Development, Swedish University of Agriculture Sciences.

Smyth, I. (2007). Taking of Gender: Words and Meaning in Development', in A. Cornwall and D. Eads (eds.), Deconstructing Development Discourse: Buzzwords and Fuzzwords, Practical Action publishing and Oxfam: Rugby, pp.143-152. 
Surani, M. (2011). Impact Assessment Report of the Job Project (Swat) USAID, PDMA/PaRRSA. Available at http://www.pdma.gov.pk/PaRRSA/ documents/impact_assessment_report_January_2011.pdf

WB \& ADB (2009). Preliminary Damage and Need Assessment, Immediate Restoration and Medium-Term Reconstruction in Crisis Affected Areas, World Bank and Asian Development Bank Islamabad, Pakistan. Available at http://www.pdma.gov.pk/PaRRSA/documents/DNA.pdf, Date: 12-112012

Dr. Noor Elahi is an Assistant Professor in the Department of Development Studies, COMSATS University Islamabad, Abbottabad Campus. 